\title{
Origin and differentiation of the endocrine cells of the ovary
}

\author{
A. G. Byskov, P. E. Høyer* and L. Westergaard $\dagger$ \\ Laboratory of Reproductive Biology II, Section 4112, Department of Obstetrics and Gynecology, \\ Rigshospitalet, Blegdamsvej 9, DK-2100 Copenhagen $\emptyset ;{ }^{*}$ Institute of Medical Anatomy, Department A, \\ The Panum Institute, Blegdamsvej 3, DK-2200 Copenhagen $N$, and $\dagger$ Department of Obstetrics and \\ Gynecology, Section 537, Hvidovre Hospital, Kettegards Alle 30, DK-2650 Hvidovre, Denmark
}

\begin{abstract}
Summary. A large proportion of the somatic cells of the developing ovaries of mouse, human and rabbit stems from the mesonephric tissue. In the immature mouse ovary and in the 19-day-old fetal rabbit ovary, the first steroid-producing cells differentiate among the mesonephric-derived cells within the ovary. In the fetal human ovary, the first steroid-producing cells arise in the inner part of the cortex and differentiate concomitantly with the formation of small follicles. The origin of the early steroidproducing cells in the human ovary is still uncertain.

During early ovarian development, formation and further differentiation of the steroid-producing interstitial cells seem to continue only in areas devoid of free viable germ cells.
\end{abstract}

\section{Introduction}

The endocrine cells of the ovary are often considered to be identical with the steroid-secreting cells, those cells that are mainly involved in the production of progesterone, androgens and oestrogens. However, the ovary is also involved in other types of endocrine secretions, e.g. inhibin, substances which interfere with the control of meiosis and possibly other intraovarian substances, which locally may control follicular growth and differentiation. In this study we shall deal exclusively with the steroid-secreting cells.

The adult ovary contains many types of steroid-secreting cells, the granulosa cells, theca, lutein cells and interstitial cells. In addition, in many species, prominent endocrine tissues are found in the hilar region of the ovary. All of these steroid-secreting cells seem to be equipped with the different enzymes involved in steroid synthesis. With the exception of granulosa cells, they also share many ultrastructural features which characterize typical steroid-producing cells, such as mitochondria with tubular cristae, well developed smooth endoplasmic reticulum and various amounts of lipid droplets. Also, the granulosa cells gain these characteristics when the follicle luteinizes either after ovulation or on some occasions during degeneration.

The similar physiological and morphological features of these cells might indicate a common origin. Experimental and morphological studies of fetal and immature ovaries have provided some evidence that the different steroid-secreting cells of the developing ovary arise from the same source, the mesonephros or its derivatives (Byskov, Skakkebaek, Stafanger \& Peters, 1977; Høyer \& Byskov, 1981; Grinsted, 1982).

Different patterns of early ovarian development provide models in which origin and differentiation of various types of steroid-producing cells can be studied. In some species, the ovary is not capable of synthesizing steroids de novo until the first follicles with theca cells are formed (e.g. mouse, rat, man). In such species the early differentiating ovary is a compact organ in which the oogonia enter meiosis shortly after gonadal sex differentiation. They have been termed 'species with immediate meiosis' (Byskov, 1979). In other species, ovarian steroids are produced during an early transitory stage of development, long before follicles are formed (e.g. sheep, pig, rabbit). In these 
ovaries, more or less distinct cell cords containing oogonia differentiate soon after the sex of the gonads can be recognized. Simultaneously, a transitory de-novo synthesis stops around the time when the oogonia enter meiosis. Since meiosis is delayed in respect to gonadal sex differentiation, these species have been termed 'species with delayed meiosis' (Byskov, 1979). The period between sex differentiation and onset of meiosis during which oestrogens are produced is called the delay period'.

Common to all these mammalian species is that the gonads, the ovary as well as the testis, develop in intimate contact with the mesonephric tissue (Upadhyay, Luciani \& Zamboni, 1979; Zamboni, Upadhyay, Bézard, Luciani \& Mauleon, 1980; Wartenberg, 1983). From very early stages of gonadal formation mesonephric cells migrate into the gonadal anlage. In species with delayed meiosis the invading mesonephric cells take up a prominent part of the hilar or central area of the ovary, forming large endocrine tissues (e.g. ferret, horse) (Mossman \& Duke, 1973). However, in species with immediate meiosis the invading mesonephric cells mix with the germ cells and form less distinct cell masses in the centre of the ovary (e.g. mouse) (Byskov \& Lintern-Moore, 1973).

It has been proposed that the differentiation of the early steroid-producing cells of the gonads is dependent on the enclosure of germ cells in specific germ cell compartments (Byskov, Yding Andersen \& Westergaard, 1983). The aim of this study is to present further evidence for the mesonephric origin of the steroid-secreting cells of the fetal and immature ovary and to discuss some of the mechanisms involved in differentiation of these cells.

\section{Materials and Methods}

\section{Animals}

Two species with immediate meiosis, the mouse and man, and one species with delayed meiosis, the rabbit, were used. In all cases ovaries with the attached mesonephric tissue were studied.

Mouse. Immature mouse ovaries, 7 and 14 days old after birth, with the mesonephric remnants were processed for light and electron microscopy.

Man. Fetal human ovaries and mesonephroi 9, 11, 13, 14, 20 and 23 weeks of fetal age were studied. Light microscopy was performed at all ages. Immunocytochemical assay for hCG was carried out on sections from 9-, 11- and 13-week-old fetuses. Moreover, assays for 3 $\beta$-hydroxysteroid dehydrogenase (3 $\beta$-HSD) and NADH diaphorase were performed on fresh frozen sections obtained from ovaries of 14-, 20- and 23-week-old fetuses.

Rabbit. Fetal rabbit ovaries and mesonephroi of Day 19 were removed for light and electron microscopy and for assays of $3 \beta$-HSD activity.

\section{Electron microscopy}

The tissue was fixed in $3 \%$ glutaraldehyde, post-fixed in $1 \%$ osmium tetroxide, dehydrated in ethanol and embedded in Epon 812. In addition to ultrathin sections, $1 \mu \mathrm{m}$ sections were cut and stained with toluidine blue.

\section{Enzyme cytochemistry}

Whole fetal rabbit ovaries with their attached mesonephroi were frozen in $n$-hexane precooled to $-70^{\circ} \mathrm{C}$ by an ethanol/solid $\mathrm{CO}_{2}$ slurry. Sections were cut at $8 \mu \mathrm{m}$ with a motorized Brights cryostat using constant speed of sectioning to ensure uniformity of section thickness.

The incubation media and detailed procedures used for the demonstration of enzyme activities have been fully described elsewhere (Høyer \& Byskov, 1981). To find the relevant parts of the tissues, some sections were occasionally incubated for $5 \mathrm{~min}$ at $37^{\circ} \mathrm{C}$ in the medium used for 
demonstration of NADH diaphorase activity. When a representative part had been found, con-

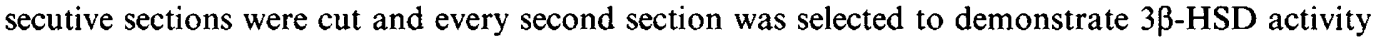
using dehydroepiandrosterone as the substrate. The remaining sections were incubated in medium omitting the substrate. All $3 \beta$-HSD assays were run at $37^{\circ} \mathrm{C}$. Sections from fetal rabbit tissues were incubated for $30 \mathrm{~min}$ and those from human fetal ovaries for $60 \mathrm{~min}$.

The amount of final reaction product deposited in the fetal rabbit ovaries was measured by using a Vickers M85A scanning and integrating microspectrophotometer. The following machine settings were employed: a $\times 40$ objective, light of $585 \mathrm{~nm}$, flying spot 1 (diameter $0.5 \mu \mathrm{m}$ at $\times 40$ ) and a field mask size B1 (scanning area of $707 \mu \mathrm{m}$ ). Measurements were made in 20 scanning fields in both the medulla and the cortex in each of 5 sections per ovary. The mean value and the standard error of the mean were calculated. The mean value was then corrected by subtracting the mean recorded in a similar number of scanning fields in each of 5 sections incubated without the substrate. Finally, the relative absorption values were expressed as mean integrated absorbance by reference to a calibration graph.

\section{Immunohistochemistry}

The tissue samples were immersion-fixed in Bouin's solution for $24 \mathrm{~h}$ at $4^{\circ} \mathrm{C}$. The fixed blocks were then dehydrated, cleared, and embedded in paraffin wax. Serial sections $5 \mu \mathrm{m}$ in thickness were cut with constant speed using a motorized microtome, placed on clean slides, and dried overnight at $37^{\circ} \mathrm{C}$. The sections were dewaxed in xylene and transferred to two baths of absolute methanol, each for $4 \mathrm{~min}$.

The immunohistochemical localization of hCG was accomplished by employing the unlabelled antibody peroxidase-antiperoxidase (PAP) technique. The sections were placed in a freshly prepared mixture of $5 \mathrm{ml} 30 \% \mathrm{H}_{2} \mathrm{O}_{2}$ and $200 \mathrm{ml}$ absolute methanol for $15 \mathrm{~min}$ at room temperature to destroy any possible endogenous peroxidase activity. After 2 changes for 2 and $1 \mathrm{~min}$ in $70 \%$ methanol, the sections were rinsed 3 times for $10 \mathrm{~min}$ and allowed to dry. This rinsing bath, and all those mentioned later, consisted of $0.05 \mathrm{M}-\mathrm{Tris}-\mathrm{HCl}, \mathrm{pH} 7.4$, containing $0.1 \%$ Nonidet. The sections were then incubated for 15 min with $20 \%$ normal swine serum in $0.05 \mathrm{M}$-Tris- $\mathrm{HCl}$ buffer, pH 7.4, to suppress non-specific staining. Excess medium was tapped off leaving a thin layer coating the sections, which were then incubated in specific rabbit anti-hCG antiserum (Dakopatts,

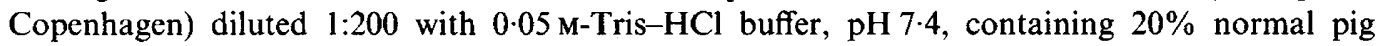
serum. The incubation was performed in a moist chamber for $12 \mathrm{~h}$ at $4^{\circ} \mathrm{C}$. After decanting and washing 3 times for $5 \mathrm{~min}$ in the rinsing solution, the sections were incubated for $30 \mathrm{~min}$ at room temperature in pig anti-rabbit $1 \mathrm{gG}$ serum (Dakopatts, Copenhagen) diluted 1:20 with Tris- $\mathrm{HCl}$ buffer, $\mathrm{pH} 7 \cdot 4$. The sections were again washed 3 times for $5 \mathrm{~min}$ in the rinsing buffer and incubated for $30 \mathrm{~min}$ at room temperature with horseradish peroxidase-rabbit anti-horseradish peroxidase antiserum (Dakopatts, Copenhagen) diluted 1:50 with $20 \%$ normal pig serum in $0.05 \mathrm{M}-\mathrm{Tris}-\mathrm{HCl}$ buffer, $\mathrm{pH} 7 \cdot 4$. After washing 3 times for $5 \mathrm{~min}$ in the rinsing buffer, the slides were placed for 10

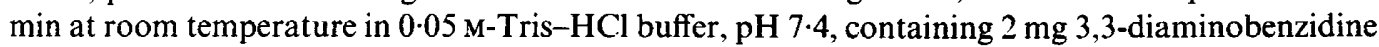
tetrahydrochloride/ $\mathrm{ml}$ (Sigma, St Louis, MO, U.S.A.). This solution also contained 0.01 imidazole (Sigma) to improve the sensitivity of the chromogenic reaction (Straus, 1982; Trojanowski, Obrocka \& Lee, 1983). After decanting, this procedure was repeated for another $10 \mathrm{~min}$, but now with $0.015 \% \mathrm{H}_{2} \mathrm{O}_{2}$ in the medium. The incubation was terminated in two 5-min changes of $0.05 \mathrm{M}$-Tris- $\mathrm{HCl}$ buffer at $\mathrm{pH} 7.4$. Finally, the sections were dehydrated through an ascending series of alcohols, cleared and mounted with DPX.

Two control procedures were carried out on adjacent sections. In one series, the first specific antiserum was replaced by normal rabbit serum. In another series, normal rabbit immunoglobulin fraction (Dakopatts, Copenhagen) with a known protein concentration was used instead of the first specific antiserum. This immunoglobulin fraction was diluted to give the same total protein concentration as in the step in which the first specific antiserum was employed. 


\section{Results and Discussion}

\section{Mouse}

In the fetal and immature mouse ovary, the mesonephric connection has been described as consisting of three contiguous parts, the extraovarian rete, the connecting rete and the intraovarian rete (Byskov \& Lintern-Moore, 1973; Byskov, 1978). During early folliculogenesis, the intraovarian rete cords are connected to the developing granulosa layer. Individual follicles form when the basal lamina of the granulosa layers interrupts the connection to the intraovarian rete cells, closing the follicular germ cell compartment.

Quantitative cytochemical studies of $3 \beta-H S D$ in the immature mouse ovary from Day 1 to Day 21 after birth have shown that the extraovarian and connecting rete cells have no detectable 3ß-HSD activity (Høyer \& Byskov, 1981). The intraovarian rete cords, including the attached granulosa cells of the centrally developing follicles, gain activity between Day 4 and 7 . However, in some growing follicles in which the rete connection is being eliminated, the granulosa cells lose the enzyme activity when situated close to the oocyte. In contrast, the $3 \beta-\mathrm{HSD}$ activity of the intraovarian rete cords without connection to follicles and oocytes increases steadily. All rete cells with enzyme activity also contain lipid droplets (Høyer \& Byskov, 1981) (Pl. 1, Fig. 1). The number of lipid droplets is low or absent in the extraovarian and connecting rete at all ages, whereas $t^{1} i$ amount of lipid increases in the intraovarian rete, concomitantly with the increase of $3 \beta$-HSD. These intraovarian rete cells are identical with the primary interstitial tissue and early differentiating theca cells.

The present study shows that the cells of the extraovarian and the connecting rete at 7 and 14 days after birth possess mitochrondria with lamellar cristae and rough endoplasmic reticulum. In addition, all rete cells contain small dense bodies (Pl. 1, Fig. 2), which previously have been described as markers of mesonephric derived cells of the developing mouse and pig ovaries (Byskov, 1978). On Day 14, most of the endoplasmic reticulum of the intraovarian rete cells has acquired a smooth appearance. Only a few mitochondria have tubular cristae, the majority still being of the lamellar type (Pl. 1, Fig. 2).

In some cases, growing oocytes of healthy appearance are found within the intraovarian rete cords. Rete cells in close proximity to such oocytes have no or few lipid droplets and a granular endoplasmic reticulum, in contrast to the lipid-containing rete cells remote from the oocyte (P1. 1, Fig. 3). It has been suggested that the presence of granulosa cells lacking lipid droplets and having lost their $3 \beta$-HSD activity situated close to the oocytes of growing follicles indicates that these follicles are healthy (Høyer \& Byskov, 1981). It is possible that healthy growing oocytes exert an inhibitory influence on certain steps of steroidogenesis during early follicular formation. The role of the oocyte in regulation of granulosa cell luteinization has previously been studied intensively in large follicles. Some studies provide evidence that the oocyte inhibits granulosa cell luteinization (El Fouley, Cook, Nekola \& Nalbandov, 1970; Nekola \& Nalbandov, 1971), whereas others fail to demonstrate this effect (Nicosia, 1972; Tsafriri \& Channing, 1977).

The nature of the inhibitory effect which seems to be exerted by the oocyte of the early developing mouse follicles is not necessarily identical with that proposed to operate in the large follicles:

\section{PLATE 1}

Fig. 1. A 14-day-old mouse ovary, $1 \mu \mathrm{m}$ plastic section, toluidine-blue stained. Arrows indicate the invading mesonephric cells which form the intraovarian rete. Note numerous lipid droplets. $\times 260$.

Fig. 2. Intraovarian rete cell of a 14-day-old mouse ovary showing lipid droplets, a smooth endoplasmic reticulum and small dense bodies (arrow) $\times 22000$.

Fig. 3. Intraovarian rete cord of a 14-day-old mouse containing a growing oocyte. Cells close to the oocyte contain virtually no lipid droplets. $\times 4900$. 


\section{PLATE 1}
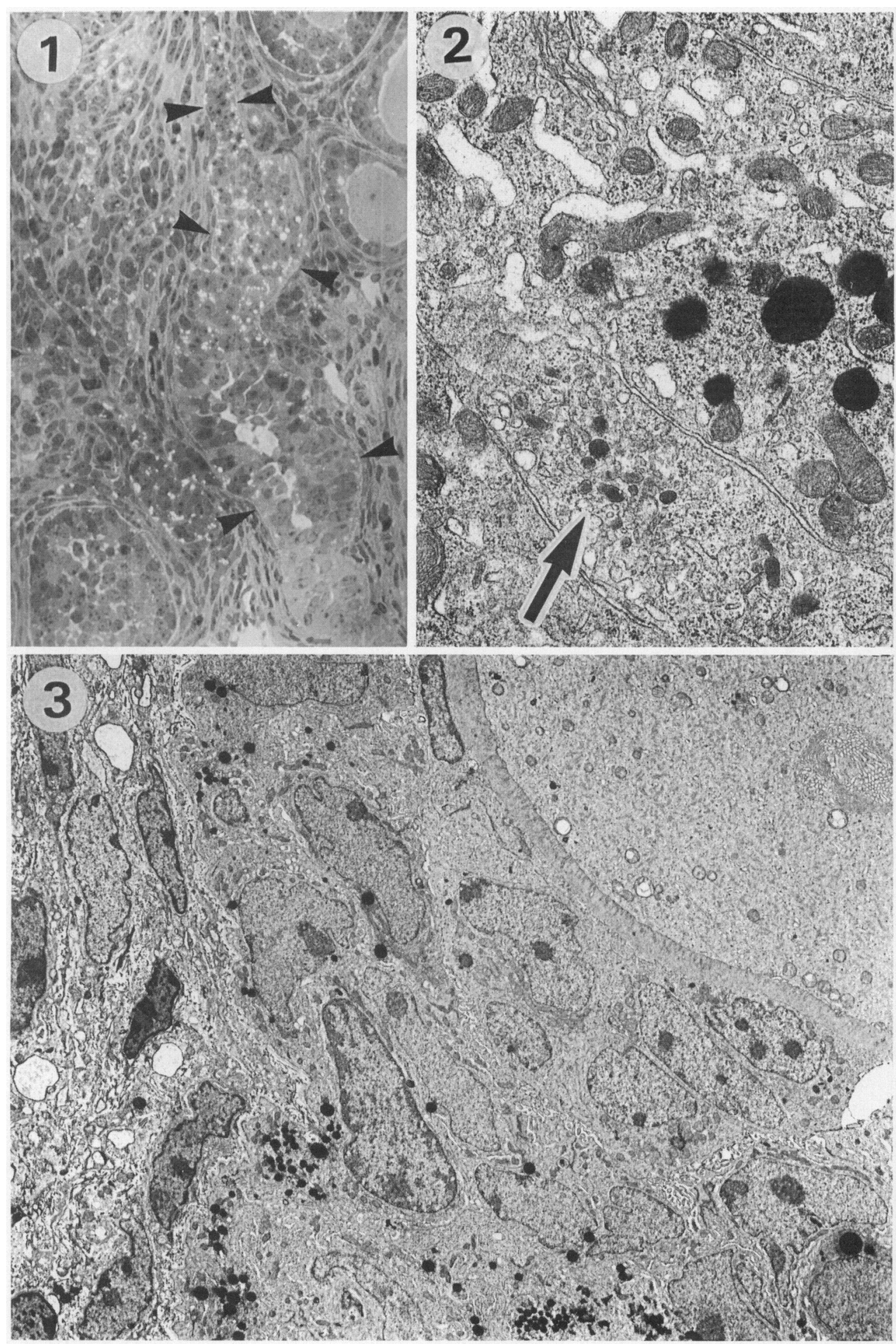

(Facing p. 302) 


\section{PLATE 2}
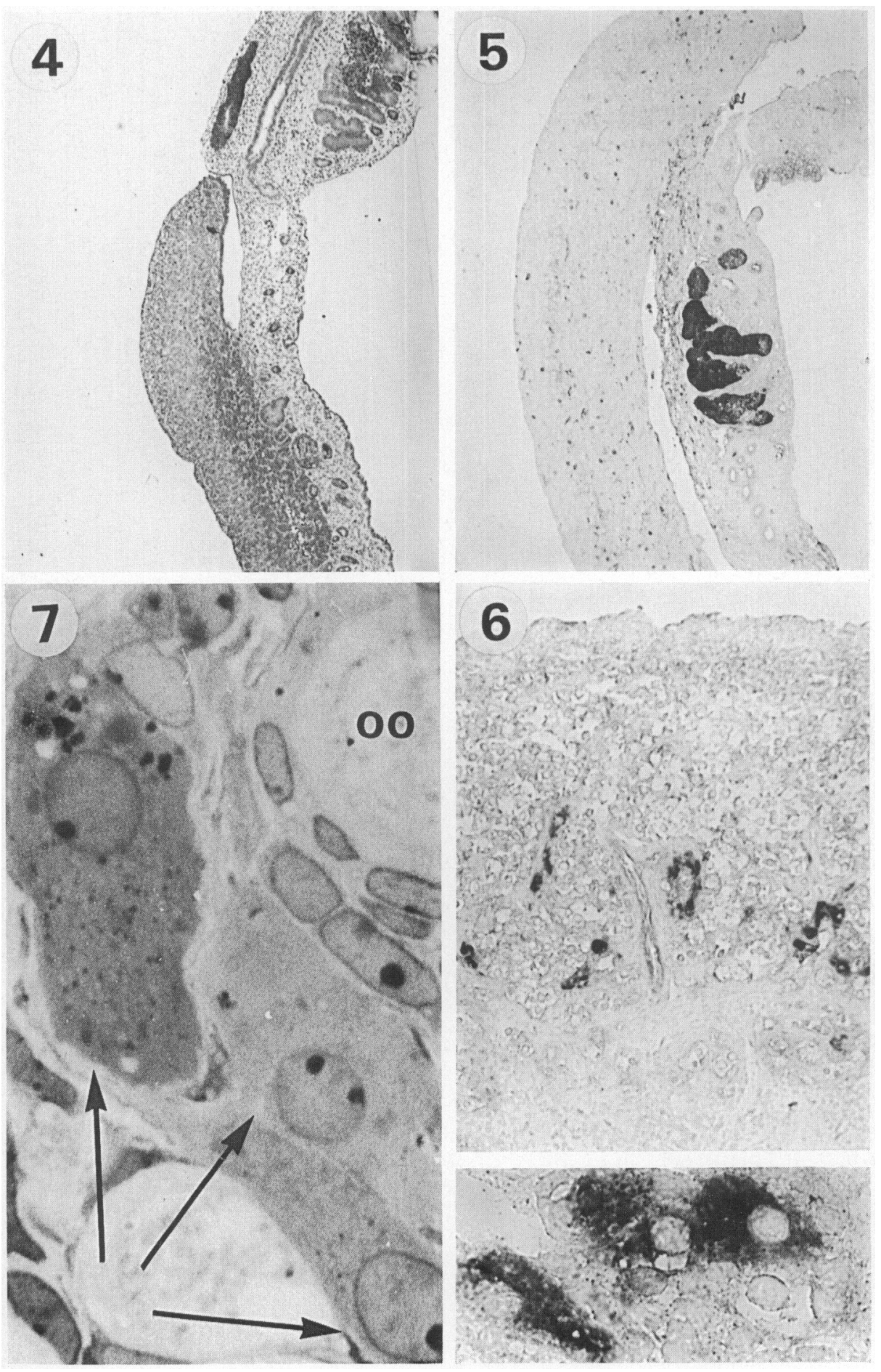


\section{PLATE 3}
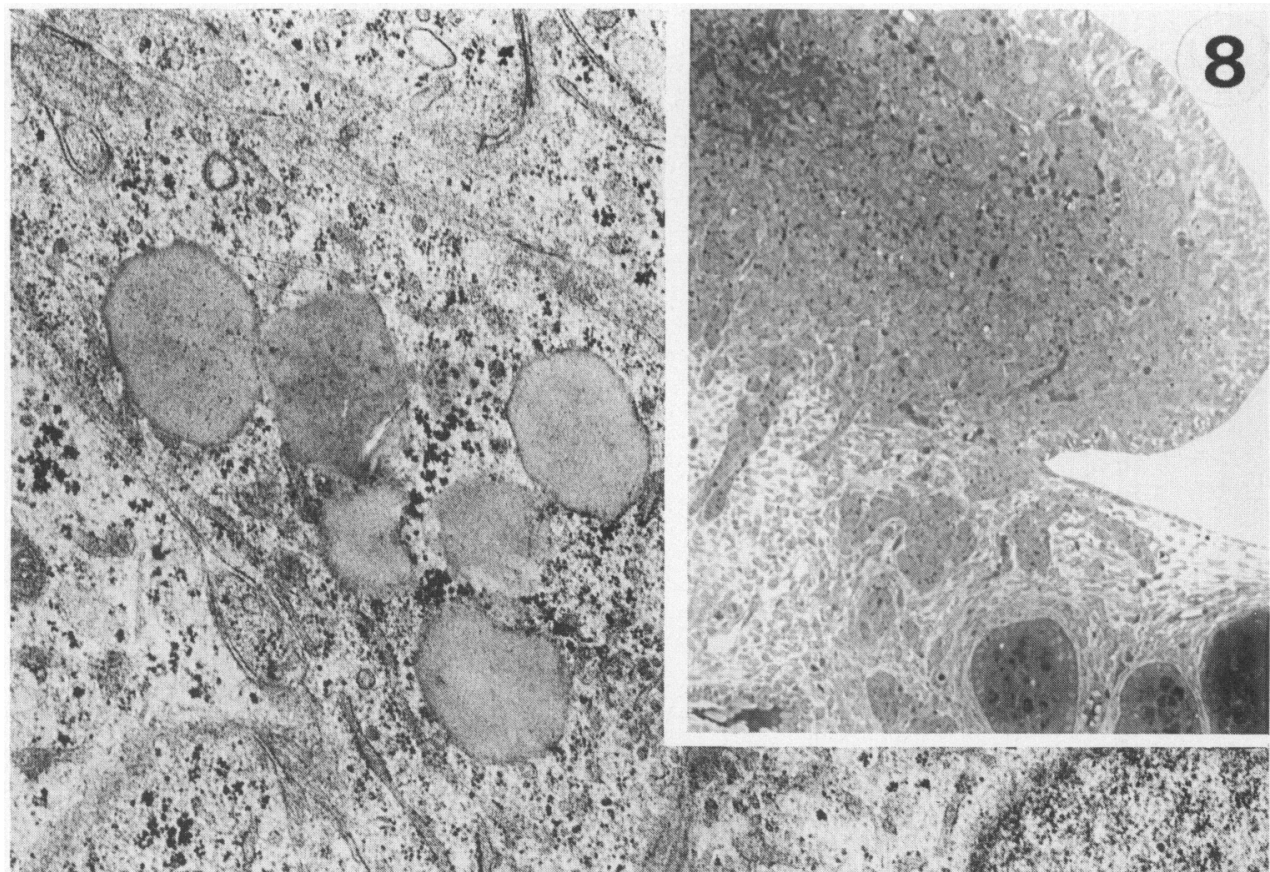

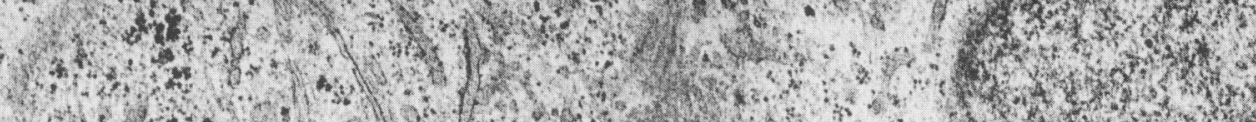

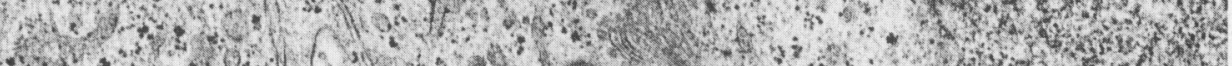

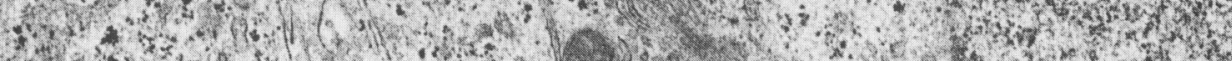

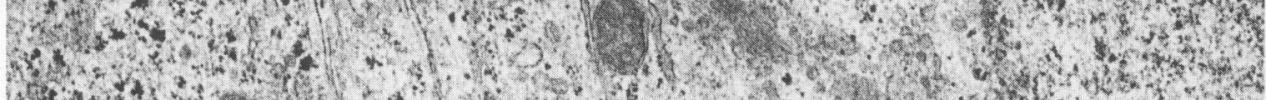

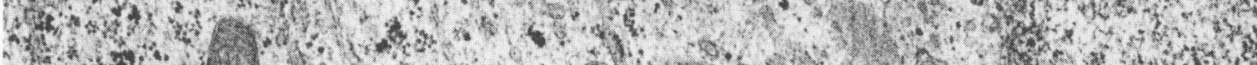
2.

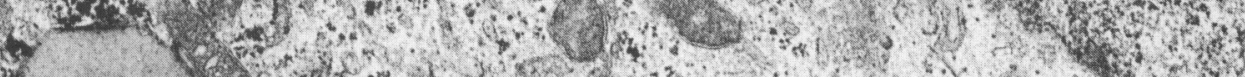

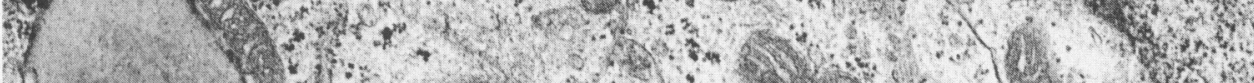

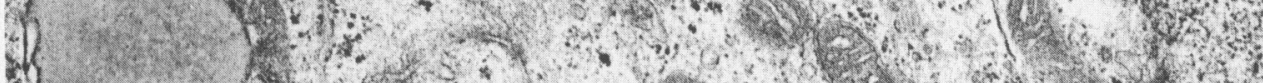

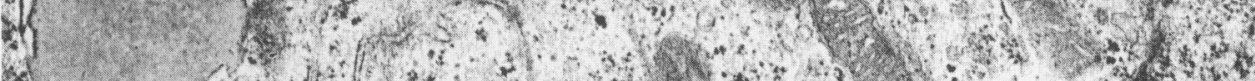

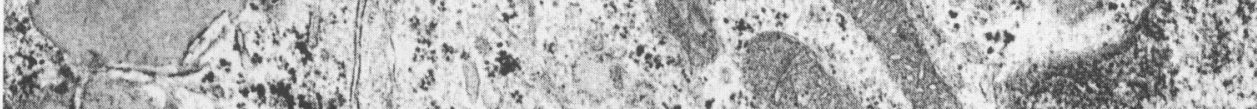

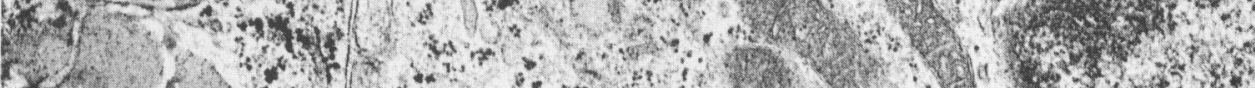

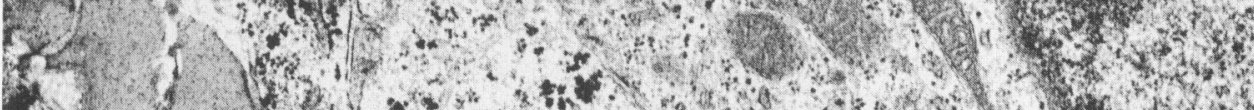

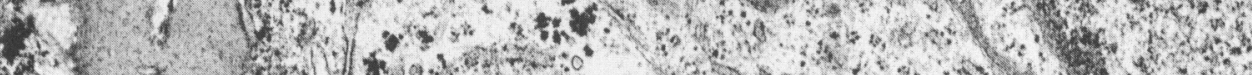

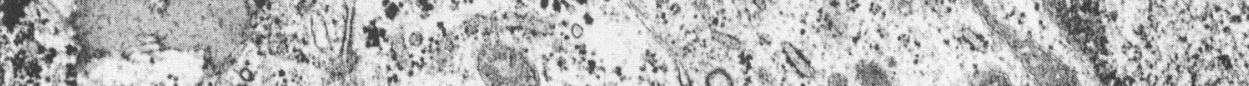

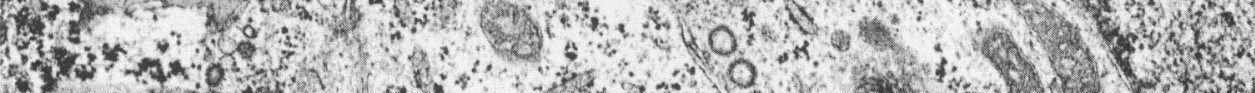

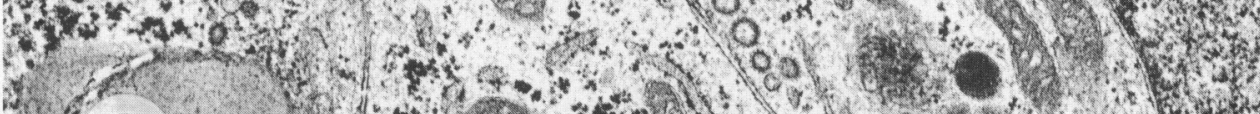

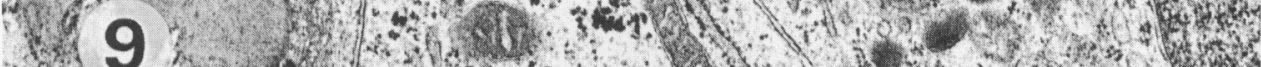

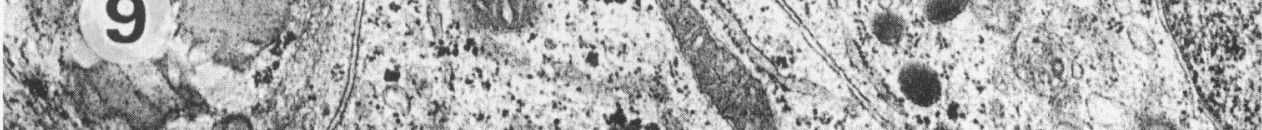


The rete-connected granulosa cells of all the small developing follicles in the immature mouse ovary gain a positive reaction for $3 \beta-\mathrm{HSD}$, but lose it again when the oocyte and granulosa cells start to grow in the enclosed follicular unit. It appears that in the immature mouse ovary the granulosa cells, the theca cells and the interstitial cells are all connected to the intraovarian rete system; they all gain $3 \beta$-HSD activity at the same time, but only those cells that are being enclosed in follicles lose it again.

\section{Man}

From very early stages of human gonadal formation, cells of the mesonephros invade the gonadal anlage (Wartenberg, 1982). Plate 2, Fig. 4 shows the intimate contact between the mesonephros and the ovary of a 9-week-old human fetus. In the human fetus, there is still no conclusive evidence that early steroidogenesis and folliculogenesis depend on the supply of mesonephric cells, although morphogenesis of the human ovary basically is identical with that of other mammals (Wartenberg, 1981, 1982, 1983).

No or minimal amounts of sex steroid hormones are produced by the fetal human ovary before follicles start to form, although the aromatizing system is functioning as early as from the 8th week (George \& Wilson, 1978). The human testis secretes vast amounts of steroids during the same period (Winter, Faiman \& Reyes, 1977). In the fetal testis, characteristic Leydig cells differentiate from the 8th week, whereas in the ovary interstitial cells with similar appearance are observed only after the 12th week (Gondos \& Hobel, 1973). From the 10th to the 20th week, exogenous hCG can stimulate steroidogenesis of human testes (Huhtaniemi, 1977). During this period, hCG is present in the testis and surprisingly also in the ovary, even in much higher concentrations (Huhtaniemi, Korenbrot \& Jaffe, 1978). These findings led us to investigate whether cells of the developing ovary (9-13 weeks) contain bound hCG.

Our immunohistochemical assays show that very few hCG-positive cells are seen in the 9-weekold ovary, but the number increases slightly to the last tested age, the 13th week. The hCG-positive cells are found mainly in the cortex (P1. 2, Fig. 5). By their size and shape, sparse cytoplasm and

\section{PLATE 2}

Fig. 4. Ovary of a 9-week-old human fetus with intimate contact to mesonephros. Toluidineblue stained, $1 \mu \mathrm{m}$ plastic section. $\times 100$.

Fig. 5. Ovary and mesonephros of an 11-week-old human fetus showing immunohistochemical staining of hCG. Particularly strong staining is seen in mesonephric tubules. Only a few scattered cells in the ovarian cortex are stained. $\times 100$.

Fig. 6. Ovary of 20-week-old human fetus showing strong NADH diaphorase activity in cells located in the inner part of the cortex. $\times 75$. Inset: Weak or moderate $3 \beta-H S D$ activity is seen in some of these cells. $\times 380$.

Fig. 7. Peripheral part of the ovarian cortex of a 23 -week-old human fetus. Three interstitial cells (arrow) are seen in the vicinity of a small growing follicle. Note the varied content of osmiophilic granules in these cells indicating different degrees of differentiation. $\times 1000$.

\section{PLATE 3}

Fig. 8. Ovary of a 19-day-old rabbit fetus with the cortex containing germ cells and the medulla consisting of a condensed cell mass of mesonephric-derived cells. Note cells moving out of the basal part of a mesonephric Malpighian body and mesonephric cell cords joining the basal area of medulla (arrows). $\times 250$.

Fig. 9. Lipid-containing medullary cells of a 19-day-old rabbit fetus. The cells contain glycogen, small dense bodies and the endoplasmic reticulum is partly agranular. $\times 22000$. 
spherical, centrally placed nucleus they appear to be germ cells, not interstitial cells. It has been proposed that gonadotrophins may influence survival and differentiation of oogonia (Winter et al., 1977). The mesonephric tubules show intense immunohistochemical staining of hCG at all three ages (Pl. 2, Fig. 5). The functional significance of this finding is unknown.

The enzyme histochemical assays show that at the 14th week a few scattered cells with high $\mathrm{NADH}$ diaphorase activity are situated in the innermost part of the cortex. No significant activity of $3 \beta-H S D$ can be detected at this age. A higher number of diaphorase-positive cells appears at the

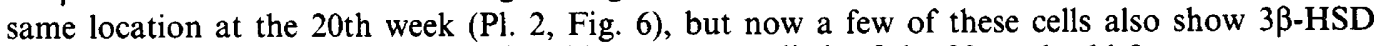
activity (insert in Pl, 2, Fig. 6). In the oldest ovary studied, of the 23-week-old fetus, many more cells exhibit diaphorase as well as $3 \beta-H S D$ activity. Although most of these cells are still located in the inner part of the cortex, some also have a more peripheral location. The cells with activity of both enzymes resemble Leydig cells in size, shape and the eccentrically placed spherical nucleus (Pl. 2, Fig. 6). These characteristics are also clearly seen in $1 \mu \mathrm{m}$ plastic sections (Pl. 2, Fig. 7). Moreover, the pattern of formazan deposition indicates that some of the cells contain numerous lipid droplets. These cells are sometimes positioned close together in small groups and of ten in the vicinity of blood vessels (Gondos, Bhiraleus \& Hobel, 1973; Høyer, 1980). Individual cells in a group may show moderate, weak or no activity of $3 \beta$-HSD. The morphology visualized in semithin sections confirms this heterogeneity (Pl. 2, Fig. 7).

The morphological and enzymic pattern of differentiation of these somatic cells seems to indicate that they are the first cells in the human fetal ovary having some of the necessary prerequisites for de-novo steroid synthesis, and that they are in fact interstitial cells. Winter et al. (1977) suggested that the low amount of steroids produced by the human fetal ovary occurs in the interstitial cells.

The concomitant appearance and the position within the ovary of the interstitial cells and the developing follicles suggest that the closing up of the follicle may locally interact with the early differentiation of the extrafollicular steroid secreting cells.

\section{Rabbit}

The delay period of the rabbit begins on Day 16 of fetal life, when the gonadal sex differentiates, and terminates by the time of birth, 14 days later, when meiosis starts (Grinsted, 1982). The 19-dayold fetal rabbit ovary has a thin rim of cortex containing many germ cells and a prominent medulla consisting of a condensed mass of mesonephric-derived cells and very few germ cells (Wartenberg, 1981) (Pl. 3, Fig. 8). The ovary during the delay period is able to synthesize in vitro small amounts of oestradiol de novo (Milewich, George \& Wilson, 1977; Grinsted, 1982) with a maximum on Day 19 (George, Simpson, Milewich \& Wilson, 1979). Ultrastructural studies on the somatic cells of the rabbit ovary during the delay period failed to demonstrate all the organelles typical for steroidproducing cells (Gondos, George \& Wilson, 1983). However, many cells contained lipid droplets. By using a point-counting method it was found that the maximal content of lipid per cell occurred on Day 19.

Our study shows that the lipid-containing cells on Day 19 almost exclusively belong to the condensed cell mass of medulla, although some lipid droplets are also contained in the invading mesonephric cells (Pl. 3, Fig. 8). The mesonephric-derived cells possess small dense bodies as in the fetal mouse (Pl. 3, Fig. 9). The cristae of the mitochondria are of the laminar type and the endoplasmic reticulum is mainly granular, confirming the observations by Gondos et al. (1983). However, in the lipid-filled medullary cells the endoplasmic reticulum is partly smooth. In addition, glycogen granules are seen in these cells (Pl. 3, Fig. 9).

The quantitative evaluation of $3 \beta$-HSD shows a weak but significant activity in the lipidcontaining medullary cells, the absorbance not exceeding $0.046 \pm 0.005$ (s.e.m.). However, we find no reaction in the cortex. The low $3 \beta$-HSD activity of the entire fetal rabbit ovary (Milewich et al., 1977 ) is therefore confined to the medullary part and not to the cortex. 
As in the rete system of the immature mouse, the invading mesonephric cells acquire $3 \beta-H S D$ activity only when they reach into the ovary proper. The reason for the lack of this enzyme activity in the cortical area is unknown. It has been suggested that only few of the mesonephric cells have invaded the peripheral part of such young ovaries (Wartenberg, 1983). Another possibility could be that the oogonia inhibit the differentiation of the somatic cells situated in their vicinity.

\section{Conclusion}

The early steroid-producing cells of the rabbit ovary differentiate among the medullary mesonephric-derived cells long before follicles form. In the immature mouse ovary and in the fetal human ovary, the initial steroid-producing cells differentiate only at the time when the follicles begin to grow.

We thank Mrs Birgitte Olesen, Mr Keld Ottosen, Mrs Inga Husum, Mrs Bodil Mathiesen and Mrs Kirsten Jepsen for skilful technical assistance; Mrs Karen Grüning for the typing; and Dr Bernard Gondos for correcting the manuscript. This work is supported by grants from Nordic Insulin Foundation.

\section{References}

Byskov, A.G. (1978) The anatomy and ultrastructure of the rete system in the fetal mouse ovary. Biol. Reprod. $19,720-735$.

Byskov, A.G. (1979) Regulation of meiosis in mammals. Annls Biol. anim. Biochim. Biophys. 19, 1251-1262.

Byskov, A.G. \& Lintern-Moore, S. (1973) Follicle formation in the immature mouse ovary: the role of the rete ovarii. J. Anat. 116, 207-217.

Byskov, A.G., Skakkebaek, N.E., Stafanger, G. \& Peters, H. (1977) Influence of ovarian surface epithelium and rete ovarii on follicle formation. $J$. Anat. 123, 77-86.

Byskov, A.G., Yding Andersen, C. \& Westergaard, L. (1983) Dependence of the onset of meiosis on the internal organization of the gonad. In Current Problems in Germ Cell Differentiation, pp. 215-224. Eds A. McLaren \& C. C. Wiley. Cambridge University Press.

El Fouley, M., Cook, B., Nekola, M. \& Nalbandov, A.V. (1970) Role of the ovum in follicular luteinization. Endocrinology 87, 288-293.

George, F.W. \& Wilson, J.D. (1978) Conversion of androgen to estrogen by the human fetal ovary. $J$. clin. Endocr. Metab. 47, 550-555.

George, F.W., Simpson, E.R., Milewich, L. \& Wilson, J.D. (1979) Studies on the regulation of the onset of steroid hormone biosynthesis in fetal rabbit gonads. Endocrinology 105, 1100-1106.

Gondos, B. \& Hobel, C.J. (1973) Interstitial cells in the human fetal ovary. Endocrinology 93, 736-739.

Gondos, B., Bhiraleus, P. \& Hobel, C.J. (1971) Ultrastructural observations on germ cells in human fetal ovaries. Am. J. Obstet. Gynec. 110, 644-652.

Gondos, B., George, F.W. \& Wilson, 3.D. (1983) Granulosa cell differentiation and estrogen synthesis in the fetal rabbit ovary. Biol. Reprod. 29, 791-798.

Grinsted, J. (1982) Influence of mesonephros on foetal and neonatal rabbit gonads. II. Sex-steroid release by the ovary in vitro. Acta endocr., Copenh. 99, 281-287.
Høyer, P.E. (1980) Histoenzymology of the human ovary: dehydrogenases directly involved in steroidogenesis. In Biology of the Ovary, pp. 52-67. Eds P. M. Motta \& E. S. E. Hafez. Martinus Nijhoff, The Hague.

Høyer, P.E. \& Byskov, A.G. (1981) A quantitative cytochemical study of $\triangle 5,3 \beta$-hydroxy steroid dehydrogenase activity in the rete system of the immature mouse ovary. In Development and Function of Reproductive Organs, pp. 216-224. Eds A. G. Byskov \& H. Peters. Excerpta Medica, Amsterdam.

Huhtaniemi, I. (1977) Studies on steroidogenesis and its regulation in human fetal adrenal and testis. $J$. Steroid Biochem. 8, 491-497.

Huhtaniemi, I.T., Korenbrot, C.C. \& Jaffe, R.B. (1978) Content of chorionic gonadotropin in human fetal tissues. J. clin. Endocr. Metab. 46, 994-997.

Milewich, L., George, F.W. \& Wilson, J.D. (1977) Estrogen formation by the ovary of the rabbit embryo. Endocrinology 100, 187-196.

Mossman, H.W. \& Duke, K.L. (1973) Comparative Morphology of the Mammalian Ovary. University Wisconsin Press, Wisconsin.

Nekola, M.V. \& Nalbandov, A.V. (1971) Morphological changes of rat follicular cells as influenced by oocytes. Biol. Reprod. 4, 154-160.

Nicosia, S.V. (1972) Luteinization of rabbit preovulatory granulosa cells cultured in vitro in presence of follicular oocytes. I. Growth characteristics and progestin biosynthesis. Fert. Steril. 23, 791-801.

Straus, W. (1982) Imidazole increases the sensitivity of the cytochemical reaction for peroxidase with diaminobenzidine at a neutral pH. J. Histochem. Cytochem. 30, 491-493.

Trojanowski, J.Q., Obrocka, M.A. \& Lee, V.M.-Y. (1983) A comparison of eight different chromagen protocols for the demonstration of immunoreactive neurofilaments or glial filaments in rat cerebellum 
using the peroxidase-antiperoxidase method and monoclonal antibodies. J. Histochem. Cytochem. 31, $1217-1223$.

Tsafriri, A. \& Channing, C.P. (1977) Lack of an inhibitory influence of oocytes upon luteinization of porcine granulosa cells in culture. J. Reprod. Fert. 50, 103-105.

Upadhyay, S., Luciani, J.M. \& Zamboni, L. (1979) The role of the mesonephros in the development of the indifferent gonads and ovaries of the mouse. Annls Biol. anim. Biochim. Biophys. 19, 1179-1196.

Wartenberg, H. (1981) The influence of the mesonephric blastema on gonadal development and sexual differentiation. In Development and Function of Reproductive Organs, pp. 3-12. Eds A. G. Byskov \& H. Peters. Excerpta Medica, Amsterdam.

Wartenberg, H. (1982) Development of the early human ovary and role of the mesonephros in the differentiation of the cortex. Anat. Embryol. 165, 253-280.
Wartenberg, H. (1983) Structural aspects of gonadal differentiation in mammals and birds. In Differentiation, pp. 64-71. Eds U. Muller \& W. W. Franke. Springer Verlag, Berlin.

Winter, J.S.D., Faiman, C. \& Reyes, F.I. (1977) Sex steroid production by the human fetus: its role in morphogenesis and control by gonadotropins. In Morphogenesis and Malformation of the Genital System, pp. 41-58. Eds R. J. Blandau \& D. Bergsma. Alan R. Liss, New York.

Zamboni, L., Upadhyay, S., Bezard, J., Luciani, J.M. \& Mauléon, P. (1980) The role of the mesonephros in the development of the mammalian ovary. In Endocrine Physiopathology of the Ovary, pp. 3-42. Eds R. 1. Tozzini, G. Reeves \& R. L. Pineda. Elsevier/ North-Holland, Amsterdam.

Received 3 October 1984 